Published in final edited form as:

J Behav Med. 2018 December ; 41(6): 875-889. doi:10.1007/s10865-018-9944-5.

\title{
Past, Present or Future?: Word Tense and Affect in Autobiographical Narratives of Women with HIV in Relation to Health Indicators
}

\author{
Yudelki M Firpo-Perretti ${ }^{1}$, Mardge H Cohen ${ }^{2}$, Kathleen M Weber ${ }^{2}$, and Leslie R Brody ${ }^{1}$ \\ ${ }^{1}$ Department of Psychological and Brain Sciences, Boston University \\ ${ }^{2}$ Cook County Health and Hospitals System and Hektoen Institute of Medicine
}

\begin{abstract}
Autobiographical narratives allow people to organize and make sense of complex life experiences in ways that reflect their identity, goals, and values (Boals et al., 2011; Boals \& Klein, 2005; Klein \& Boals, 2010; Ramirez-Esparza \& Pennebaker, 2006). Writing or talking about emotional and personal experiences has been found to benefit health, including self-reported depression, anxiety and well-being (Lepore, 1997; Stanton et al., 2002; Sloan \& Marx, 2004); academic and occupational performance (Francis \& Pennebaker, 1992; Pennebaker \& Francis, 1996), and utilization of medical services and immune functioning (Pennebaker \& Beall, 1986; Pennebaker, Kiecolt-Glaser, \& Glaser, 1988; Pennebaker \& Graybeal, 2001; Lepore \& Greenberg, 2002; Sloan \& Marx, 2004). Among individuals with HIV, writing about emotional topics (compared to writing about neutral events) was related to decreased viral load at two weeks follow-up and increased CD4+ lymphocyte counts (with higher levels indicating healthier immune functioning) at six weeks post-writing (Petrie et al., 2004). Immune cells are continually being activated, generated, and utilized by the immune system to protect the body against infection and there is cross-talk between the immune system (sometimes referred to as our "sixth sense") and the central nervous system (Ziemssen \& Kern, 2007); therefore the ways in which people narrate their life stories, and the emotions that are generated, may affect ongoing immune processes.
\end{abstract}

\footnotetext{
Yudelki Firpo-Perretti (Corresponding Author), yfirpo@bu.edu; Phone: 646-427-6408,Department of Psychological and Brain Sciences, Boston University,648 Beacon Street, Room 227, Boston, MA 02215. Mardge H. Cohen, M.D., mardge.cohen@ gmail.com; Phone: 312-925-5660, Cook County Health and Hospitals System \& Hektoen Institute of Medicine, Chicago IL. 2225 W. Harrison, Suite B, Chicago IL. Kathleen M. Weber, R.N., kathleen.weber@hektoen.org; Phone: 312-953-1486, Cook County Health and Hospitals System \& Hektoen Institute of Medicine, Chicago IL., 2225 W. Harrison, Suite B, Chicago IL. Leslie R. Brody, Ph.D., lrbrody@gmail.com; Phone: 617-353-3544, Department of Psychological and Brain Sciences, Boston University, 648 Beacon Street, Room 227, Boston, MA 02215.

Conflict of Interest:

Author A declares that she has no conflict of interest. Author B declares that she has no conflict of interest. Author C declares that she has no conflict of interest. Author D declares that she has no conflict of interest.

Ethical approval:

All procedures performed in this study involving human participants were in accordance with the ethical standards of the institutional and/or national research committee and with the 1964 Helsinki declaration and its later amendments or comparable ethical standards. This article does not contain any studies with animals performed by any of the authors.

Informed consent:

Informed consent was obtained from all individual participants included in the study.
} 
The current study focuses on understanding linguistic features of autobiographical narratives in women with HIV as relating to their HIV health behaviors and immune functioning. Previous research has demonstrated that the particular patterns of words people used in when narrating significant life events and categorization and counting of distinct word types in narratives can be more informative than the thematic content (Newman et al., 2003; Pennebaker \& Graybeal, 2001). Linguistic features of narratives, including pronouns and affect words, have been found to significantly relate to aspects of personality, social and situational context, as well as mental and physical health (Chung \& Pennebaker, 2008; Pennebaker et al., 2003). Specifically, we examined how the frequency of positive and negative affect words and tense use (present, past, and future) expressed in autobiographical narratives relate to health measures concurrently $(\mathrm{Tl})$ and at a three to nine-month follow-up (T2). These health indicators were HIV biomarkers (i.e., HIV viral load and CD4 T lymphocyte cell count, both measures of immune functioning), as well as to a health behavior, antiretroviral therapy (ART) medication adherence. Understanding the linguistic features in narratives, in particular individuals' affective expression and temporal focus, that relate to immune functioning and medication adherence can serve as a basis for better understanding the factors that affect the health of this vulnerable population.

Studies of health in relation to positive and negative emotions have included measures of both the expression and the experience of emotions. It has been demonstrated that expressing positive emotions, especially sharing them with others who respond in validating ways, boosts the experience of the original positive emotion (Lambert et al., 2013), so that experience and expression of emotion may be synergistic. Numerous studies show that experiencing positive affective states, measured with ecological momentary assessments or self-reports, relates to favorable physical and psychological well-being (Dockray \& Steptoe, 2010; Fredrickson \& Levenson, 1998; Steptoe et al., 2009; Tugade \& Fredrickson, 2004), including health outcomes such as effective emotion regulation, faster cardiovascular recovery from emotional arousal induced by stressful events (Fredrickson \& Levenson, 1998; Tugade \& Fredrickson, 2004), decreased vulnerability to upper respiratory infection (Cohen et al., 2003), and better antibody response to hepatitis B vaccination (Marsland et al., 2006). Among individuals with HIV, higher positive emotional experiences assessed via self-report are predictive of engaging in HIV care three months after receiving the diagnosis, continued use of antiretroviral medications, and viral suppression (Carrico \& Moskowitz, 2014; Wilson et al., 2016). In contrast, excessive and/or prolonged experiences of negative affect can be detrimental to health behaviors and are associated with worse physical and psychological health (Cohen et al., 2001; Smith et al., 2004). For instance, self-reported anxiety and perceived stress experienced over a one to three month period relate to worse physical and psychological health, including the suppression of immune response to immunization (Cohen et al., 2001). However, specific forms of negative affect (e.g., sadness vs. anger) may have differing motivational pathways and physiological responses (Bodenhausen et al., 1994; Carver \& Harmon-Jones, 2009; Schwartz et al., 1981).

Expressing emotional experiences (measured via self-report scales and narrative or conversational content) has also been found to significantly relate to mental and physical health (Esterling et al., 1994; Pennebaker et al., 1997; Pennebaker \& Seagal, 1999; Petrie et al., 2004). Generally, a higher ratio of negative to positive affect words in narrative writing 
relates to worse follow-up health indicators (e.g., physician visits, physical symptoms) in student, community, and incarcerated samples; while a higher ratio of positive to negative affect words relates to better health outcomes (Pennebaker et al., 1997). As consistent with this, Rude et al. (2004) found that depressed individuals used more negative affect words in narratives than did non-depressed individuals. However, relative frequencies of positive and negative affect expressed in narratives are not always respectively associated with positive and negative health behaviors or indicators. For example, (Pennebaker et al., 1997) showed that an increased relative frequency of positive affect words over time when talking about stressful life events related to increased distress at follow-up. And among older men of higher socioeconomic status, moderate levels of self-reported expressed anger, compared to lower levels, were found to be protective against cardiovascular disease (Eng et al., 2003).

There are several possible explanations for these contradictory data on how the expression of positive and negative emotions relates to health. First, researchers have suggested that expressing any type of emotion (positive or negative) helps to regulate emotional experiences (Greenberg, Wortman, Stone 1996), facilitates cognitive and emotional processing (Lepore, Ragan, \& Jones 2000) and may also elicit positive support from others (Lambert et al., 2013), all of which may benefit health. Moreover, some evidence suggests that it is the coping strategies used to regulate specific types of emotions, rather than the expression of emotions themselves, that may better predict health. For example, in a prospective study examining cardiovascular risk and anger expression during a structured interview, discussing anger in a destructive justification way (i.e., blaming others for one's anger) predicted increased risk for cardiovascular heart disease, even when accounting for depressive symptoms, hostility, and anxiety (Davidson \& Mostofsky, 2010). However, writing letters to people or things that participants were most angry at was found to decrease depression and increase control over pain, with higher levels of expressed anger in the letters significantly relating to better outcomes (Graham et al., 2008). Further, positive and negative emotions are not unitary constructs, and the types of negative emotions (e.g., sadness vs. anger) or positive emotions (e.g. pride vs. warmth) expressed may have differential effects.

Another possible explanation for the contradictory findings regarding the effects of expressed positive and negative affect on health is that such relationships may be moderated by the temporal focus (e.g., past, present, future) within which the affect words are embedded. Theories support the idea that the consequences of negative vs. positive affect expression may differ depending on the time frame referenced, both the time frame for the experience of the affect (i.e. the present vs. the past being referenced) as well as the time frame of the health consequences (i.e. concurrent versus longer term). For example, Carver, (2001) suggests that some forms of negative affect (e.g., anger) expressed about current unfulfilling circumstances motivate us to change them which leads to adaptive future effects. However, ruminating on past negative experiences relates to depression, negative cognitive styles, and negative psychological health outcomes (Lam et al., 2003). The literature on mindfulness (a non-judgmental focus on the present) suggests that a present-moment focus on either positive or negative emotions is adaptive for health because it allows psychological resources to be brought to bear as events unfold, as opposed to a focus on the past or the future (Weinstein, Brown, \& Ryan, 2009). Moore and Brody (2009) found that increases in the frequency of present tense words in narratives written daily over a 3-day period 
significantly predicted increased self-reported mindfulness (non-judgmental acceptance of present-moment experiences) at a four to eight-week follow-up period.

Frederickson's "broaden and build" theory also highlights the importance of temporal context for emotions (Fredrickson, 2001). She suggests that an emotion begins with an individual's assessment of the personal meaning of an antecedent event. This appraisal process initiates a cascade of response tendencies, such as subjective experience, facial expression, cognitive processing, and physiological changes. Experiencing negative affect is theorized to narrow a person's momentary thought-action repertoire in current threatening situations, activating "quick and decisive" actions that may lead to "direct and immediate benefit" (Fredrickson, 2001). However, these actions may not necessarily be adaptive for long term health. In contrast, positive emotions broaden attention and cognitive processes, and expand the kinds of thoughts and actions that come to mind. Positive emotions, because they broaden thinking, are theorized to have a reciprocal relationship with finding positive meaning in events and can build long term resilience in the face of challenging events (Frederickson, 2001).

In the context of women with HIV, expressing positive emotions about past events may aid in making meaning, which is especially important because $67 \%$ of women with HIV have a history of physical and sexual abuse (Cohen et al., 2000), and meaning making in the face of abuse has been shown to benefit mental health (Wright, Crawford, \& Sebastian, 2007). In turn, these benefits may facilitate self-care behaviors and adhering to ART going forward (Carrico, Johnson, Colfax, \& Moskowitz, 2010; Carrico \& Moskowitz, 2014), which is critical for survival and stopping the spread of the disease (Chesney, 2003). Expressing negative emotions about present events may promote taking quick actions to address current problems and might have immediate benefits, possibly for health care behaviors such as ART adherence. Both positive and negative affect about the future (including perceptions of future health threats or risks such as cancer and associated regrets) may serve as motivational antecedents that predict expectations of physical health (Carver et al., 2010) and engagement in healthy behaviors (e.g., exercise; Kahana et al., 2005). However, positive affect about the future may be associated with beneficial longer term health than negative future-oriented thinking, given that positive emotions build coping resources that continue to grow and can be later retrieved in the face of future challenges (Fredrickson, 1998, 2001; Fredrickson \& Branigan, 2005). Thus, positive thinking about an imagined future may motivate continued proactive coping efforts to achieve desired goals. In contrast, negative affect about the future may be associated with a greater likelihood of "giving-up" and a lower likelihood of planning or taking proactive steps to achieve goals over time (Carver et al., 2010; Schou et al., 2005).

No known studies have made direct comparisons of the effects of expressions of negative vs. positive affect words used when focusing on the past, present, and future on health, concurrently and over time. Most studies on linguistic features of narratives have focused independently on either word tense or affect and have not examined the interaction between affect and word tense in relation to both present and longer-term health. In addition, no known studies have looked at how these linguistic markers are related to changes in health over time. The current study investigates the relationships between affect expression and 
tense used in narratives, and health indicators concurrently (T1), and 3-9 months later (T2) adjusting for health indicators at T1, in women with HIV. The women were participants in a 20-year longitudinal cohort study, which presents a unique opportunity to study the relationship between linguistic markers with immune functioning over time. It is important to note that the narratives were told in the presence of health care providers who were trained to provide supportive reflective listening. Because the women's expression of emotions in the narratives was supported and validated, it may have synergistically or reciprocally affected their ongoing emotional experiences (Lambert et al., 2013).

The specific aims of the current study were to examine the main effects of and interactions between linguistic tense (past, present, and future-tense words) and linguistic affect valence (positive and negative affect words) in autobiographical narratives of women with HIV in relation to (a) concurrent (T1) health behaviors (adherence to ART) and HIV biomarkers (HIV viral load, and CD4+ cell counts); and (b) changes in ART adherence and HIV biomarkers between $\mathrm{T} 1$ and $\mathrm{T} 2$. Based on previous literature reviewed above, especially studies emphasizing present-moment awareness (Moore \& Brody, 2009; Weinstein, Brown, \& Ryan, 2009), Frederickson's broaden and build theory (Fredrickson, 2001), and Carver's work on the motivational pathways of emotions (Carver, 2001) hypotheses were that: There would be main effects such that (1) a higher present tense frequency would significantly relate to higher T1 CD4+ cell counts, ART adherence, and undetectable VL, and a higher past tense frequency would significantly relate to lower T1 CD4+ cell counts, ART adherence, and undetectable viral load. The main effects between future tense word frequency and CD4+ cell counts, ART adherence, and undetectable VL will be explored. These main effects would be qualified by interactions between affect valence $\mathrm{x}$ tense as follows: (2) The expression of positive affect about past events (suggesting meaningmaking) would be associated with a positive change in biomarkers from T1 to T2; (3) The expression of negative affect about present events (enabling immediate actions to address stressors) would be associated with higher T1 undetectable viral load, CD4+ cell count, and ART adherence, whereas the expression of negative affect about the past (suggesting rumination and a depressive cognitive style) would be associated with lower T1 undetectable viral load, CD4+ cell count, and ART adherence and negative changes in biomarkers and ART adherence from T1 to T2; and (4) The expression of positive affect about future events (suggesting optimism) would be associated with higher T1 undetectable viral load, CD4+ cell count, and ART adherence and with positive changes in biomarkers and ART adherence from $\mathrm{T} 1$ to $\mathrm{T} 2$.

\section{Method}

\section{Participants}

Participants were from the Chicago site of the Women's Interagency HIV Study (WIHS), a longitudinal cohort study of US women with and at risk for HIV, enrolled during three waves ( $1=1994-1995 ; 2=2001 ; 3=2010-2011$; see Barkan et al., 1998 for more details $)$. The current study took place from 2008-2012 and included a convenience sample of 98 HIV + women $(n=43$, wave 1 , and $n=55$, wave 2 ), who were mostly African American women 
$(90.8 \%)$ and averaged 45.32 years of age $(S D=8.87) .68 .3 \%$ of women reported an income of or below $\$ 12,000$ at T1. (See Table 1 for sample demographics).

WIHS participants attend semi-annual visits during which they complete a structured interview, physical and gynecologic examinations, and specimen collections (see Barkan et al., 1998 for more details). A listing of previously published papers including participants from the WIHS study may be found here: https://statepi.ihsph.edu/wihs/wordpress/ publications/. Only one previous paper has investigated the autobiographical narratives of a subgroup of 20 women with a focus on thematic content indicating resilience (Brody et al., 2016). In 2008-2012, either during a regularly scheduled WIHS visit or during a separate metabolic study visit within 3 months of a regularly scheduled WIHS visit, T1 data collection for the current study took place. The T2 health outcomes were collected at the participants' subsequent WIHS study visit, three to nine months after time 1 (elapsed average amount of time in months $M=5.72, S D=1.51$ ). WIHS visits occur approximately at six-month intervals, with the possibility that some participants who attended a visit at the beginning of a six month interval of data collection, would attend their subsequent visit more than six months after that visit. Similarly, participants who attended their visit near the end of a six month visit interval, are likely to have their next visit less than six months subsequently. These logistics (along with the fact that some women's T1 data were collected up to three months later than their previous regularly scheduled WIHS visit) account for the six-month range in the elapsed time between $\mathrm{T} 1$ and $\mathrm{T} 2$.

Women were excluded from the study if they did not speak English and therefore could not complete standardized measures and/or did not have in-person clinic visits and therefore could not complete face-to-face interviews. Written informed consent was obtained for all enrolled women after the study was approved by the Cook County Health and Hospital Systems and Boston University Institutional Review Boards. Participants received a financial payment of $\$ 25$ in support of their time and effort and reimbursement for transportation.

\section{Measures}

\section{Guided Autobiography Task (GAT; McAdams, 2006).}

An adapted version of the GAT (McAdams, 2006) was used, in which the participants for this study told narratives about three key self-defining memories they considered turning points in their lives. The participants were asked to describe what happened in the event, when it happened, who was involved, and what they were thinking and feeling during the event. They were also asked to describe how the experiences influenced the person they are today. Narratives were told to a supportive listener (a nurse or a social worker who worked with women living with HIV) who was trained to do reflective non-judgmental listening, asking for clarifications or elaborations when necessary. The participants' autobiographical narratives were transcribed and analyzed using the Linguistic Inquiry and Word Count 2007 (LIWC2007) program (LIWC; Pennebaker, et al., 2007). The LIWC 2007 program uses word counts to search close to 4500 words and word stems, categorizes them into linguistic dimensions, and then converts the raw counts to percentages of total words (Pennebaker et al., 2007). The variables used in the present study were frequency of positive affect words (e.g., love, nice, sweet), negative affect words (e.g., hurt, ugly, nasty), past tense words (e.g., 
went, ran, had), present tense words (e.g., is, does, hear), and future tense words (e.g., will, gonna). Using a sample of 2800 randomly selected text files, Pennebaker and colleagues (2007) evaluated the internal reliability of the LIWC by using two methods: (1) determining the correlation between frequency of use of each word in a category and the sum of the other words in the same category; (2) using a binary method that converts the usage of each single words within a given text into either 0 (not used) or 1 (used one or more times) and then calculating a percentage of total words used from each categories. Using these two approaches, the following was reported for the target linguistic studies used in this study (showing raw alpha values and then the binary alpha values): positive emotion ( $a=.40 / .97)$, negative emotions ( $a=.61 / .97)$, past tense words ( $a=.75 \mathrm{~A} 97)$, present tense words $(a=$. 94/.91), future tense words ( $a=.02 / .75$ ). Pennebaker and colleagues (2007) provide initial external validity statistics based on 72 narratives collected in an earlier study (Pennebaker \& Francis, 1996). Using these narratives, four judges were asked to rate the emotional, cognitive, content, and composition dimensions designs corresponding to the LIWC word count categories. These judges' ratings were then compared to the LIWC output using Pearson correlations (for more details, see Pennebaker et al., 2007). Other studies have provided additional support for the external validity of the LIWC program, for instance, by comparing coding methods between the LIWC and other computerized coding (Alpers et al., 2005; Bantum \& Owen, 2009; Kahn et al., 2007; Tausczik \& Pennebaker, 2010). Further, the LIWC was developed within the context of Pennebaker, Francis, \& Booth's (2001) work on emotional autobiographical writing and it has been used to reliably determine the linguistic features of narratives that predict subsequent health outcomes (Pennebaker \& Francis, 1996; Pennebaker et al., 1997).

For descriptive purposes, the autobiographical narratives in this study were also coded for the major content themes the participants described in their narratives by two independent groups of three coders each (undergraduate and graduate students in psychology), who coded for presence (1) or absence (0) of one major theme for each narrative. Women were given scores for major themes based on an average across three narratives - e.g., if they talked about abuse as a major theme in two out of three narratives, their score for abuse as a major theme would be .67 . Reliability between groups for the three most frequent themes is reported in the Results section below.

\section{Antiretroviral Therapy (ART) Adherence.}

To measure ART adherence, participants reported the percentage of the specific pills taken in the past 6 months using one of five category responses: $1=100 \%$ of the time, $2=95-99 \%$ of the time, $3=75-94 \%$ of the time, $4=<75 \%$ of the time, $5=$ I haven't taken any of my prescribed medications. Previous studies using this self-report measure have found it to relate to health outcomes and to yield data consistent with objective measures (Walsh, Mandalia, \& Gazzard, 2002). Furthermore, a review of studies using self-reported adherence indicates that, although potentially susceptible to social desirability and recall bias, selfreported adherence to antiretroviral medications differentiated clinically meaningful medication-taking behavioral patterns (Nieuwkerk \& Oort, 2005). Specifically, lower selfreported adherence rates were associated with higher odds of having a detectable viral load (Nieuwkerk \& Oort, 2005). In this study, a categorical variable was created reflecting 
medications taken $>95 \%$, versus $<95 \%$ of the time despite it being medically indicated (based on having a CD4 count $<350$ through 2009 or a CD4 count $<500$ after 2009). This conservative cut-off of $95 \%$ adherence was used based on previous studies that demonstrate that at a cut-off of $95 \%$ adherence to anti-retroviral medications, HIV RNA loads of <400 copies/mL occurred $80 \%$ of the time in patients with levels of antiretroviral therapeutic adherence of $>95 \%$ (Paterson et al., 2000) and that adherence rates below $95 \%$ are associated with increased mortality risk among individuals with HIV (Abaasa et al., 2008). In this sample of participants, $>95 \%$ adherence rates at $\mathrm{T} 1$ was associated with undetectable viral load at $\mathrm{T} 1, X^{2}(1, \mathrm{~N}=96)=14.89, p<.001$. Similarly, $>95 \%$ were associated with undetectable viral load at $\mathrm{T} 2, X^{2}(1, \mathrm{~N}=87)=17.17, p<.001$. Consistent with previous research, these results demonstrate how high rates of adherence are associated with undetectable viral load, a clinically meaningful result.

\section{HIV disease markers.}

Blood specimens were analyzed for HIV RNA load and CD4 + cells, given in copies per milliliter of blood. During the time of the narrative administration, a viral load was considered undetectable if less than 80 copies/ml of HIV RNA load were found in the blood samples; therefore, for this study viral load was dichotomized as detectable (> $80 \mathrm{copies} / \mathrm{ml}$ ) or undetectable ( $<80$ copies $/ \mathrm{ml}$ ) based on the equipment's detection limit at the time of this study. Further, because ART was considered medically indicated for women with HIV who had CD4+ cells $/ \mathrm{mm}^{3}$ count below $350, \mathrm{CD} 4+$ cells $/ \mathrm{mm}^{3}$ were dichotomized as CD4 >350 or $<350$. While the investigators considered examining the HIV biomarkers and ART adherence as continuous, these were only examined as dichotomous variables given their clinically significant cut-offs and as consistent with a large body of HIV research that uses similar cut-offs (e.g., Coovadia et al., 2007; De Luca et al., 2000; Terzian et al., 2009).

\section{Statistical Analysis}

Data were analyzed using the Statistical Package for the Social Sciences (SPSS 20, 2011). All covariates, independent variables, and dependent variables were standardized by converting them to z-scores prior to conducting analyses. For descriptive purposes, preliminary analyses examined the relationships between all tense and affect predictors, the participants' age and education, income, and the wave of recruitment for WIHS participation (wave 1 = 1994-1995; wave 2 = 2001) using Pearson correlations. Further, age and wave of recruitment were examined in relation to the health indicators at T1 and T2 using Pearson correlations. Given the past literature indicating that HIV infected adults who are older tend to have better adherence rates than younger HIV-infected adults (Hinkin et al., 2004; Silverberg et al., 2007), age was included as a covariate in further analyses. Additionally, in order to account for the changes in HIV care between recruitment wave 1 (year 1994-1995) and wave 2 (2001), wave of recruitment into the larger study was also included as a covariate.

Primary analyses examined the main effects of tense and affect as predictors of ART adherence, viral load, and CD4+ cell counts T1 and at T2. Models were conducted separately for each health indicator (i.e., adherence, HIV viral load, and CD4+ cell count). Results are presented in three sections corresponding to each health outcome: ART 
adherence, HIV RNA load, and CD4+ cells $/ \mathrm{mm}^{3}$. Consistent with recommendations for analyzing longitudinal data over two time points provided by Cohen, Cohen, West, and Aiken, (2013), the corresponding T1 health indicators were included as predictors of T2 health indicators (e.g., when predicting viral load at T2, viral load at T1 was included in the model). This conditional panel model allows for the removal of the potential influence of the health indicators at $\mathrm{T} 1$ on these health indicators at $\mathrm{T} 2$. We used a conditional change score model rather than calculating residualized change scores for the dependent variables because the conditional model is preferred when prior scores on a variable may affect current assessments of that variable (Finkel, 1995), which is the likely case in this study. A series of hierarchical logistic regression analyses were conducted to examine (1) the main effects of the linguistic features (use of affect words and past, present, and future tense words) on the health outcomes of CD4+ cell count, viral load and the health behavior adherence for the outcomes at T1 and T2; (2) the interactive contribution of word tense and affect words on the same health indicators. Specifically, in the first step, variables included were participant age, wave of recruitment, and, for models examining health indicators at $\mathrm{T} 2$, $\mathrm{T} 1$ health indicators corresponding to the $\mathrm{T} 2$ health outcomes. The second step included the tense words (i.e. past tense, present tense, and future tense) and affect words (i.e. negative affect words and positive affect words). The third step included the tense words by affect word interactions, meaning that all six interactions were added to the models to examine these effects as predictors of health indicators. Interaction terms were calculated by creating scores consisting of multiplying standardized scores for each variable in the interaction. Significant interactions were interpreted by plotting the regression lines at $1.0 \mathrm{SD}+$ and 1.0 SD-(See Figures $1 \& 2$ ).

\section{Results}

\section{Preliminary Analyses}

The average word count for narratives was 2072.10, $S D=1134.72$. Although 98 participants completed the autobiographical task at T1, some participants were missing data for the health indicators either at T1 or T2. Therefore, 98 and 95 participants were respectively included in analyses examining viral load at $\mathrm{T} 1$ and $\mathrm{T} 2 ; 98$ and 96 participants were respectively included in analyses examining CD4+ cells $/ \mathrm{mm}^{3}$ count and 94 and 89 participants were respectively included in analyses examining ART adherence. At T1, 82 participants were on ART and 14 were not on ART; for 12 of these 14, ART was medically indicated based on having a low CD4+ count. These 12 participants were included in the analyses as being non-adherent to ART. At T2, 77 participants were on ART, and 19 were not on ART; for 12 of these 19, ART was indicated based on CD4 count clinical cutoffs. Similarly, these 12 were included in the models as non-adherent to ART.

The four most frequent major narrative themes were HIV, trauma (including abuse, assault, witnessing domestic violence, neglect, and abandonment), positive relationships with others, including improvement in relationships overtime, and relational conflict/stress. Kappa reliabilities between two independent groups, each consisting of three coders (psychology undergraduate and graduate students) were moderate to high for each of the major themes (HIV Theme: $\kappa=1.0 ; p<.001$, Trauma Theme: $\kappa=.78, p<.001$; Positive Relationships with 
Others: $\kappa=.87, p<.001$; Relationship Conflict/Stress: $\kappa=.83, p<.001$. In the case of disagreement between the two groups, final themes were decided by thorough discussion and consensus.

Table 2 displays descriptive information regarding the predictor variables. Pearson correlations indicate that age was significantly related to being $95 \%$ adherent to ART at T1 $(r=.20, p=.048)$, and having an undetectable viral load at T1 $(r=.22, p=.027)$ and T2 ( $r=.22$, $p=.030)$. Recruitment wave was significantly related to being $95 \%$ adherent to ART at T1 $(r=-.20, p=.044)$ and T2 ( $r=-.22, p=.036)$, and having an undetectable viral load at T2 ( $r=-$. $31, p=.002)$. Income was significantly related to having 95\% ART adherence at T2 ( $r=.21$, $p=.047)$, and having an undetectable viral load at T1 $(r=.22, p=.030)$ and T2 ( $r=.22, p=.033)$. Education level was not significantly associated with any of the health indicators. Race was not included in analyses given that the vast majority of the participants were African American (89.8\%), with insufficient racial diversity to investigate race effects. With the exception of recruitment wave being significantly related to negative affect word use ( $r=.22$, $p=.033$ ), there were no significant relationships between the demographic variables and either tense words or affect words. Positive affect was related to both present tense words ( $r$ $=.48, p<.001)$; and past tense words $(r=-.32, p=.001)$, but not future tense words ( $r=.02$, $p=.82)$; and negative affect was related to past tense words $(r=.23, \mathrm{p}<.024)$ but not present tense words $(r=-.04, p=.68)$ or future tense words $(r=.08, p=.38)$.

\section{Primary Analyses}

ART adherence.-At T1, no main effects or interactions between affect valence and tense were found predicting ART adherence. See Table 3 for additional result details. At T2 (controlling for T1), past tense usage significantly predicted odds of $95 \%$ adherence, such that a higher use of past tense words was associated with lower odds of being $95 \%$ adherent to ART (OR=.48, $p=.022$ ). There were no significant interactions predicting odds of $95 \%$ adherence at T2 (See Table 4).

HIV RNA load.-At T1, the results revealed that past tense usage significantly predicted lower odds of having an undetectable viral load $(\mathrm{OR}=.53, p=.016)$. Further, present tense also predicted lower odds of having an undetectable viral load ( $\mathrm{OR}=.52, p=.024)$ word use. However, the results were qualified by a significant interaction between negative affect and present tense word use predicting viral load. The results indicate a significant crossover interaction between negative affect words and present tense words predicting odds of having an undetectable viral load (OR=2.10, $p=.023)$. Specifically, at low levels of present tense word use, a higher use of negative affect words is associated with worse odds of having an undetectable viral load. However, at high levels of present tense word use, a higher use of negative affect words is associated with better odds of having an undetectable viral load (See Figure 1). At T2 (controlling for T1), no main effects or interaction effects were found predicting HIV viral load. See Table 3 and 4 for additional details.

CD4+ cells $/ \mathrm{mm}^{3}$.-The results indicate that, at T1, a higher use of past tense words significantly predicted lower odds of having a higher CD4+ count $\left(\mathrm{CD} 4+\right.$ cells $/ \mathrm{mm}^{3}$ above 350): ( $\mathrm{OR}=.54, p=.022)$. Further, there is a significant crossover interaction between future 
tense word use and positive affect word use ( $\mathrm{OR}=1.85, p=.040)$, such that, at higher levels of future tense words, a higher use of positive affect words is associated with better odds of having CD4+ cells $/ \mathrm{mm}^{3}$ above 350 . Conversely, at lower levels of future tense words, a higher $\mathrm{u}$ se of positive affect is associated with worse odds of having CD4+ cells $/ \mathrm{mm}^{3}$ above 350. At T2 (controlling for T1), a higher use of future tense words is associated with higher odds of having CD4+ cells $/ \mathrm{mm}^{3}$ above $350(\mathrm{OR}=2.35, p=.029)$. Further, there is a significant crossover interaction between the use of positive affect and past tense word use predicting $\mathrm{CD} 4+$ cells $/ \mathrm{mm}^{3}$ above 350 at $\mathrm{T} 2$ (OR=2.96; $\left.p=.008\right)$. Specifically, at higher use of past tense words, a higher use of positive word use is associated with better odds of having CD4+ cells $/ \mathrm{mm}^{3}$ above 350 . However, at lower levels of past tense words, there is no effect of positive affect word use and odds of having CD4+ cells $/ \mathrm{mm}^{3}$ above 350. (See Figures $2 \& 3$ ) See Table 3 and 4 for additional result details.

\section{Discussion}

Our study provides evidence that, in women with HIV, linguistic features—specifically, the frequencies of words connoting tense and positive and negative affect in autobiographical narratives - relate to concurrent immune functioning, as well as changes in ART adherence and immune functioning over time. The data confirm our hypotheses that high levels of past tense word use expressed in autobiographical accounts relate to negative health behaviors and outcomes - specifically, worse adherence to ART over a three to nine-month follow-up period, as well as worse concurrent CD4+ cells/mm3 count and viral load. Also confirming our hypotheses were that past tense word use in the presence of positive affect words expressed in autobiographical accounts related to better biomarkers six months subsequently, i.e. a higher follow-up CD4+ cell count. Expressing a higher frequency of positive affect words in the context of higher future tense word usage related to higher concurrent CD4+ cells $/ \mathrm{mm} 3$ count. Finally, relatively high negative affect word usage in the context of relatively high present tense usage was predictive of a higher likelihood of having concurrent undetectable viral load. These findings add to the literature on health outcomes in people with HIV, providing evidence relating specific linguistic narrative features (affect valence and word tense) to HIV-specific health behaviors and immune functioning (Esterling et al., 1994; Pennebaker et al., 1997; Pennebaker \& Seagal, 1999; Petrie et al., 2004).

Our findings that a higher use of past tense words was related to lower concurrent CD4+ counts, concurrent undetectable viral load, and less ART adherence over time, is consistent with the view that a relatively high focus on the past when disclosing stressful life experiences, may make it difficult to adaptively respond to present moment stresses (Weinstein, Brown, \& Ryan, 2009), and perhaps compromise immune functioning (Leserman et al., 2000). However, in the context of a higher use of past tense words, using positive affect words when expressing stressful life experiences was predictive of better immune functioning, i.e., higher CD4+ cells $/ \mathrm{mm}^{3}$ above 350 , several months subsequent to narrative administration. This finding is consistent with the literature indicating that positive re-appraisal of past stressful life events is associated with good health outcomes - a process that may be related to meaning-making, or the redemption of a painful or negative experience (Cruise, 2014; McAdams, 2006). These findings are in line with the idea posited 
by Tugade and Fredrickson (2004) that positive affect may help individuals engage in healthy coping behaviors.

In the context of a higher use of future tense words, using more positive affect words also related to better concurrent health (CD4+ cells $/ \mathrm{mm}^{3}$ above 350$)$. However, using more positive affect words with lower use of future tense words was associated with concurrent worse CD4+ counts (lower odds of having CD4+ cells $/ \mathrm{mm}^{3}$ above 350 ). Thus, these results suggest that the expression of positive affect alone may not be enough to benefit health of women with HIV - but rather that expressing positive affect in the context of a past or future oriented focus may be helpful. Other research has indicated that an optimistic futureoriented view is beneficial to health (Schou et al., 2005) and serves as a motivational antecedent that predicts engagement in healthy behaviors (e.g., exercise; Kahana et al., 2005). It is possible that having positive feelings about the future helps maintain interest in tasks necessary to achieve future goals and good health (Aspinwall, 2005).

Finally, results also indicated that expressing negative affect in the context of present tense words was predictive of having better odds of having an undetectable viral load concurrently. Although these findings are focused on the expression of negative affect words and not necessarily negative emotional experiences, given the assumption that expression and experience of emotion are reciprocal and synergistic (Lambert et al., 2013), this finding provides support for Fredrickson's (2001) theoretical model that a focus on negative affect in the immediate moment serves to narrow cognitive focus and may motivate immediate change, enabling actions that may lead to "direct and immediate benefit" in current threatening situations (Fredrickson, 2001; Fredrickson \& Branigan, 2005). Another explanation for this interaction may be that individuals who used more negative affect words and higher present tense words were more insightful and aware of ongoing stressful life experiences, reflecting higher levels of cognitive and emotional processing, which has previously been linked to health benefits (Greenberg et al., 1996; Lepore, Ragan, \& Jones, 2000, Pennebaker \& Seagal, 1999).

It is also possible that the relationship between health outcomes and the frequency with which participants used affect or tense words was influenced by interactions between the content of narratives and participants' personality characteristics. More specifically, narratives with high positive affect may also have included more positive events, with positive health outcomes due to those participants actually having had fewer stressful life experiences. Further, those who used more past tense words may have been lower in experiential avoidance and higher in conscientiousness, cooperating with the task demand of narrating three events that had happened in the past. Since the majority of the sample narrated past events that were traumatic or related to their HIV diagnosis, participants who were high in avoidance or who had experienced higher levels of trauma might focus on the present or future instead of the past. Similarly, those who focused on the present might have been higher in dispositional mindfulness. These personality characteristics may have influenced health behaviors and immune functioning, perhaps mediated or moderated by emotional expression and word usage. Further research is needed to explore these possibilities. 
Noteworthy in our results, neither tense or affect word usage predicted concurrent levels of ART adherence, but at the six-month follow up, adherence was significantly negatively related to past tense usage. Perhaps this indicates that talking about the past, especially if traumatic, may reciprocally relate to subsequent negative experiences or rumination in a downward spiral that affects later health behaviors. The reverse was true of HIV viral load: at the six-month follow-up, none of the narrative word usage variables significantly related to viral load; but higher concurrent viral load did significantly relate to high past and present word tense use and lower concurrent viral load significantly related to high present tense use with high negative affect. This suggests that the way in which people linguistically process their life experiences may be related to their concurrent immune functioning, with one explanation being that having worse viral load and feeling ill might impact participants' mood states and how they perceive and narrate information about their lives. Alternatively, psychological factors such as emotional expression may mediate the cross-talk that occurs between the immunological and neurological systems, with the immune system being sensitive to emotional signals or perceptions of danger or safety so that it can maintain the body's adaptation in the face of environmental, social, and emotional stressors (Ziemssen \& Kern, 2007). As consistent with these ideas, higher levels of CD4+ count (with higher levels associated with healthier immune function), was significantly positively related to concurrent use of positive affect and future tense words (perhaps reflecting optimism), and significantly negatively related to using past tense words (perhaps reflecting a focus on or even rumination about previous traumas). Using positive affect and past tense words (perhaps reflecting meaning making) as well as future word tense was significantly positively related to higher CD4+ count six months later. The pattern of results as to how linguistic markers relate to concurrent as compared to future immune system functioning and health behaviors requires replication and further investigation.

A primary limitation of this study is the small sample size, which may have resulted in underpowered regressions which increased the probability of spurious findings. Further, the study examines a sample of women with many vulnerabilities, including ethnic minority status, having an HIV diagnosis and a significant trauma history. These demographics and multiple vulnerabilities may limit the generalizability of the study and highlight the need to replicate the study in samples with different demographics as well with larger numbers of participants. In particular, because our participants had such high levels of trauma, talking about the past may be especially stressful for them in contrast to other samples.

Nevertheless, the findings shed light on and increase our understanding of a hard-to reach and underserved population.

Another limitation of the study is that we cannot determine the specific cognitive or social processes that might account for the relationships we found between linguistic features and health outcomes. It is possible that the linguistic features of the narratives reflect a general cognitive style that affects health on an ongoing basis. The fact that there was a six-month range in when the follow-up assessment of health indicators was collected (T2), and that significant relationships were found nonetheless, suggests that the pattern of results may reflect habitual or dispositional tendencies as discussed above. Alternatively, participating in a study in which autobiographical narratives are shared with an interested listener may have therapeutic effects on emotional experiences and/or immune functioning at a subsequent 
point in time. Narrating stressful or important life experiences either orally or in writing, when compared to narrating neutral events, has been found to facilitate cognitive processing and allow for reappraisal of negative experiences, resulting in better health outcomes (Greenberg et al., 1996; Pennebaker \& Seagal, 1999), including better immune functioning (decreased viral load and increased CD4+ cell count) in men with HIV (Petrie et al., 2004).

Another limitation of the study is that the participants were asked to identify three turning points in their lives without specific instructions as to what they might discuss. The major linguistic variables of interest (tense and affect valence) were not targeted during the data collection stage, which may have masked or changed the nature of the relationships between these variables and health outcomes. Additionally, although the LIWC word categories have been used extensively and been found to relate significantly to health outcomes in previous research (Alpers et al., 2005; Bantum \& Owen, 2009; Tausczik \& Pennebaker, 2010), they are somewhat broad, may not include all words encompassing positive and negative affect, and may not correspond exactly with other categorizations of affect or word tense. However, the most frequent themes described in the narratives (e.g., trauma) were consistent with content that has emerged in other studies examining emotionally laden narratives (Petrie et al., 1995; Petrie et al., 2004). Further, the instructions allowed participants to provide an ecologically valid sample of how they tell the story of their lives, perhaps providing a more meaningful sample of word use.

It bears explanation that our findings varied across health outcome indicators. It would be more logical to expect that health indicators corroborate each other - i.e. if a participant has low viral load, they should have high adherence and a high CD4+ cell count. The discrepancies across health indicators may be due to a number of factors including: 1) individual participant differences in the magnitude of viral load prior to ART initiation (Murray et al., 1999); 2) the amount of time participants were on ART medication; prognosis is best predicted by CD4+ cell count and HIV RNA response after 6 months of treatment (Antiretroviral Therapy Cohort Collaboration et al., 2003); and 3) individual differences in rates at which HIV-1 viral load concentration declines and CD4 + cell counts recover (Kaufmann et al., 2003). However, finding significant effects on adherence, CD4+ cell counts and viral load with a small sample that was studied many years after the immediately post-ART initiation period, is a strength of the study and indicates that the way women with HIV tell the stories of their lives impacts both health behaviors and immune functioning - even long after ART therapy has been initiated. The average length of time women in this sample were on ART is 9.17 years and the range was six-months to 14.90 years.

This work provides preliminary evidence for the relationship between specific linguistic features in relation to HIV-related health outcomes among women with HIV, supporting some aspects of Frederickson's broaden and build theory (Fredrickson, 2001) as well as Carver's theoretical discussion of the motivational aspects of emotion (Carver, 2001). Women with HIV whose life stories are marked by a lack of positive affect word usage when talking about either the past or the future may be at particular risk for poor health outcomes. In contrast, the expression of negative affect words in the context of present tense words when expressing life experiences may relate to better immune functioning. Replication 
studies are needed in order to support these findings both in other samples of participants with HIV as well as community samples, to provide further evidence on the relationships among language use, health behaviors, and immune functioning, and to guide future steps to improve health.

\section{Funding}

This study was funded by the National Institute of Allergy and Infectious Diseases Grant U01-AI034993 (PIs, Dr Mardge Cohen and Dr. Audrey French) and co-funded by the National Cancer Institute and National Institute of Drug Abuse. The contents of this publication are solely the responsibility of the authors and do not necessarily represent the views of the National Institutes of Health.

\section{Acknowledgments}

We would like to thank the WIHS participants and WIHS staff, especially Sally Urwin, Cheryl Watson, \& Karlene Schowalter, who collected and managed data, and Sannisha Dale, Gwendolyn Kelso and Ruth Cruise who transcribed and coded data.

\section{References}

Abaasa AM, Todd I, Ekoru K, Kalyango JN, Levin J, Odeke E, \& Karamagi CA (2008). Good adherence to HAART and improved survival in a community HIV/AIDS treatment and care programme: the experience of The AIDS Support Organization (TASO), Kampala, Uganda. BMC Health Services Research, 5(1), 241.

Alpers GW, Winzelberg AJ, Classen C, Roberts H, Dev P, Koopman C, \& Taylor CB (2005). Evaluation of computerized text analysis in an Internet breast cancer support group. Computers in Human Behavior, 21(2), 361-376.

Aspinwall LG (2005). The psychology of future-oriented thinking: From achievement to proactive coping, adaptation, and aging. Motivation and Emotion, 29(4), 203-235.

Bantum EO, \& Owen IE (2009). Evaluating the validity of computerized content analysis programs for identification of emotional expression in cancer narratives. Psychological Assessment, 21(1), 79. [PubMed: 19290768]

Barkan SE, Melnick SL, Preston-Martin S, Weber K, Kalish LA, Miotti P, ... Feldman I (1998). The Women's Interagency HIV Study. Epidemiology, 9(2), 117-125. [PubMed: 9504278]

Boals A, Banks IB, Hathaway LM, \& Schuettler D (2011). Coping with stressful events: Use of cognitive words in stressful narratives and the meaning-making process. Journal of Social and Clinical Psychology, 30(4), 378-403.

Boals A, \& Klein K (2005). Word use in emotional narratives about failed romantic relationships and subsequent mental health. Journal of Language and Social Psychology, 24(3), 252-268.

Bodenhausen GV, Sheppard LA, \& Kramer GP (1994). Negative affect and social judgment: The differential impact of anger and sadness. European Journal of Social Psychology, 24(1), 45-62.

Brody LR, Jack DC, Bruck-Segal DL, Ruffing EG, Firpo-Perretti YM, Dale SK, ... Cohen MH. (2016). Life Lessons from Women with HIV: Mutuality, Self-Awareness, and Self-Efficacy. AIDS Patient Care and STDs, 30(6), 261-273. [PubMed: 27214648]

Carrico AW, Johnson MO, Colfax GN, \& Moskowitz JT (2010). Affective correlates of stimulant use and adherence to anti-retroviral therapy among HIV-positive methamphetamine users. AIDS and Behavior, 14(4), 769-777. [PubMed: 19125321]

Carrico AW, \& Moskowitz JT (2014). Positive affect promotes engagement in care after HIV diagnosis. Health Psychology, 33(1), 686. [PubMed: 24245846]

Carver CS (2001). Affect and the functional bases of behavior: On the dimensional structure of affective experience. Personality and Social Psychology Review, 5(4), 345-356.

Carver CS, \& Harmon-Jones E (2009). Anger is an approach-related affect: evidence and implications. Psychological Bulletin, 135(2), 183. [PubMed: 19254075] 
Carver CS, Scheier MF, \& Segerstrom SC (2010). Optimism. Clinical Psychology Review, 30(1), 879889. [PubMed: 20170998]

Chesney M (2003). Adherence to HAART regimens. AIDS Patient Care and STDs, 17(4), 169-177. [PubMed: 12737640]

Chung CK, \& Pennebaker JW (2008). Revealing dimensions of thinking in open-ended selfdescriptions: An automated meaning extraction method for natural language. Journal of Research in Personality, 42(1), 96-132. [PubMed: 18802499]

Cohen J, Cohen P, West SG, \& Aiken LS (2013). Applied multiple regression/correlation analysis for the behavioral sciences Routledge. Retrieved from https://books.google.com/books? $\mathrm{hl}=$ en $\& \mathrm{lr}=\& \mathrm{id}=$ gkalyqTMXNEC\&oi=fnd \&pg=PPl\&dq $=$ Cohen,$+\mathrm{J} .,+$ Cohen,+ P.,+ West,$+\mathrm{S} .+\mathrm{G} .,+$ $\% 26+$ Aiken, + L.+S.+(2013).+Applied+multiple +regression/correlation+analysis+for + the +behavioral+sciences.+Routledge.\&ots=tQKTZ 3p8ff\&sig=XFEocy-4UXjfSJE03fQxbbCEvW4

Cohen M, Deamant C, Barkan S, Richardson J, Young M, Holman S, ... Melnick S. (2000). Domestic violence and childhood sexual abuse in HIV-infected women and women at risk for HIV. American Journal of Public Health, 90(4), 560-565. [PubMed: 10754970]

Cohen S, Doyle WJ, Turner RB, Alper CM, \& Skoner DP (2003). Emotional style and susceptibility to the common cold. Psychosomatic Medicine, 65(4), 652-657. [PubMed: 12883117]

Cohen S, Miller GE, \& Rabin BS (2001). Psychological stress and antibody response to immunization: a critical review of the human literature. Psychosomatic Medicine, 63(1), 7-18. [PubMed: 11211068]

Collaboration AT (ART) C., \& others. (2003). Prognostic importance of initial response in HIV-1 infected patients starting potent antiretroviral therapy: analysis of prospective studies. The Lancet, 362(9385), 679-686.

Coovadia HM, Rollins NC, Bland RM, Little K, Coutsoudis A, Bennish ML, \& Newell ML (2007). Mother-to-child transmission of HIV-1 infection during exclusive breastfeeding in the first 6 months of life: an intervention cohort study. The Lancet, 369(9561), 1107-1116.

Cruise R (2014). Benefit-finding and coherence in the narratives of women with HIV Retrieved from https://open.bu.edu/handle/2144/15170

Davidson KW, \& Mostofsky E (2010). Anger expression and risk of coronary heart disease: evidence from the Nova Scotia Health Survey. American Heart Journal, 159(2), 199-206. [PubMed: 20152217]

De Luca A, Giancola ML, Ammassari A, Grisetti S, Paglia MG, Gentile M, ... others. (2000). The effect of potent antiretroviral therapy and JC virus load in cerebrospinal fluid on clinical outcome of patients with AIDS-associated progressive multifocal leukoencephalopathy. Journal of Infectious Diseases, 182(4), 1077-1083. [PubMed: 10979902]

Dockray S, \& Steptoe A (2010). Positive affect and psychobiological processes. Neuroscience \& Biobehavioral Reviews, 35(1), 69-75. [PubMed: 20097225]

Eng PM, Fitzmaurice G, Kubzansky LD, Rimm EB, \& Kawachi I (2003). Anger expression and risk of stroke and coronary heart disease among male health professionals. Psychosomatic Medicine, 65(1), 100-110. [PubMed: 12554821]

Esterling BA, Antoni MH, Fletcher MA, Margulies S, \& Schneiderman N (1994). Emotional disclosure through writing or speaking modulates latent Epstein-Barr virus antibody titers. Journal of Consulting and Clinical Psychology, 62(1), 130. [PubMed: 8034815]

Finkel SE (1995). Causal analysis with panel data. Sage Retrieved from https://books.google.com/ books?hl=en\&lr=\&id=WJI5iN-AwHEC\&oi=fnd\&pg=PR4\&dq=Finkel, +S.+E.+(1995).+Causal +analysis+with+panel+d ata+(No.+105).+Sage. $+\&$ ots=Nvy_XZ7uc5\&sig=zxipdxWbESKy5agmsGk2ZIWBSQE

Fredrickson BL (1998). What good are positive emotions? Review of General Psychology, 2(3), 300. [PubMed: 21850154]

Fredrickson BL (2001). The Role of Positive Emotions in Positive Psychology: The Broaden-andBuild Theory of Positive Emotions. American Psychologist, 56(3), 218-26. https://doi.Org/ 10.1037//0003-066X.56.3.218 [PubMed: 11315248]

Fredrickson BL, \& Branigan C (2005). Positive emotions broaden the scope of attention and thoughtaction repertoires. Cognition \& Emotion, 19(3), 313-332. [PubMed: 21852891] 
Fredrickson BL, \& Joiner T (2002). Positive emotions trigger upward spirals toward emotional wellbeing. Psychological Science, 13(2), 172-175. [PubMed: 11934003]

Fredrickson BL, \& Levenson RW (1998). Positive emotions speed recovery from the cardiovascular sequelae of negative emotions. Cognition \& Emotion, 12(2), 191-220. [PubMed: 21852890]

Graham JE, Lobel M, Glass P, \& Lokshina I (2008). Effects of written anger expression in chronic pain patients: making meaning from pain. Journal of Behavioral Medicine, 31(3), 201-212. [PubMed: 18320302]

Greenberg MA, Wortman CB, \& Stone AA (1996). Emotional expression and physical heath: Revising traumatic memories or fostering self-regulation? Journal of Personality and Social Psychology, 71(3), 588. [PubMed: 8831163]

Hinkin C EL Hardy, D. J Mason, K. I Castellon, S. A Durvasula, R. S Lam, N M., \& Stefaniak M. (2004). Medication adherence in HIV-infected adults: effect of patient age, cognitive status, and substance abuse. AIDS (London, England), 7S(Suppl 1), S19.

Kahana E, Kahana B, \& Zhang J (2005). Motivational antecedents of preventive proactivity in late life: Linking future orientation and exercise. Motivation and Emotion, 29(4), 438-459. [PubMed: 18080009]

Kahn JH, Tobin RM, Massey AE, \& Anderson JA (2007). Measuring emotional expression with the Linguistic Inquiry and Word Count. The American Journal of Psychology, 263-286. [PubMed: 17650921]

Kaufmann GR, Perrin L, Pantaleo G, Opravil M, Furrer H, Telenti A, ... others. (2003). CD4 Tlymphocyte recovery in individuals with advanced HIV-1 infection receiving potent antiretroviral therapy for 4 years: the Swiss HIV Cohort Study. Archives of Internal Medicine, 763(18), 21872195.

Klein K, \& Boals A (2010). Coherence and narrative structure in personal accounts of stressful experiences. Journal of Social and Clinical Psychology, 29(3), 256-280.

Lam D, Schuck N, Smith N, Farmer A, \& Checkley S (2003). Response style, interpersonal difficulties and social functioning in major depressive disorder. Journal of Affective Disorders, 75(3), 279283. [PubMed: 12880940]

Lambert NM, Gwinn AM, Baumeister RF, Strachman A, Washburn IJ, Gable SL, Fincham FD, (2013). A boost of positive affect: The perks of sharing positive experiences. Journal of Social and Personal Relationships 30 (1), 24-43.

Lepore S, \& Geen, Russell. (1997). Expressive Writing Moderates the Relation Between Intrusive Thoughts and Depressive Symptoms. Journal of Personality and Social Psychology, 73(5), 1030 1037. [PubMed: 9364758]

Lepore S, Ragan J, Jones S, \& Insko, Chester A. (2000). Talking Facilitates Cognitive-Emotional Processes of Adaptation to an Acute Stressor. Journal of Personality and Social Psychology, 75(3), 499-508.

Leserman J, Petitto JM, Golden RN, Gaynes BN, Gu H, Perkins DO, ... Evans DL. (2000). Impact of stressful life events, depression, social support, coping, and cortisol on progression to AIDS. American Journal of Psychiatry, 757(8), 1221-1228.

Marsland AL, Cohen S, Rabin BS, \& Manuck SB (2006). Trait positive affect and antibody response to hepatitis B vaccination. Brain, Behavior, and Immunity, 20(3), 261-269.

McAdams DP (2006). The redemptive self: Generativity and the stories Americans live by. Research in Human Development, 3(2-3), 81-100.

Moore SD, \& Brody LR (2009). Linguistic predictors of mindfulness in written self-disclosure narratives. Journal of Language and Social Psychology Retrieved from http://jls.sagepub.com/ content/early/2009/05/13/0261927X09335264.short

Murray JS, Elashoff MR, Iacono-Connors LC, Cvetkovich TA, \& Struble KA (1999). The use of plasma HIV RNA as a study endpoint in efficacy trials of antiretroviral drugs. Aids, 13(1), 797804. [PubMed: 10357378]

Newman ML, Pennebaker JW, Berry DS, \& Richards JM (2003). Lying words: Predicting deception from linguistic styles. Personality and Social Psychology Bulletin, 29(5), 665-675. [PubMed: 15272998] 
Nieuwkerk PT, \& Oort FJ (2005). Self-reported adherence to antiretroviral therapy for HIV- 1 infection and virologic treatment response: a meta-analysis. JAIDS Journal of Acquired Immune Deficiency Syndromes, 35(4), 445-448.

Paterson DL, Swindells S, Mohr J, Brester M, Vergis EN, Squier C, ... Singh, N. (2000). Adherence to protease inhibitor therapy and outcomes in patients with HIV infection. Annals of Internal Medicine, 133(1), 21-30. [PubMed: 10877736]

Pennebaker JW, Chung CK, Ireland M, Gonzales A, \& Booth RJ (2007). The development and psychometric properties of LIWC2007: LIWC.net

Pennebaker J, \& Graybeal A (2001). Patterns of Natural Language Use: Disclosure, Personality, and Social Integration. Current Directions in Psychological Science, 10(3), 90-93.

Pennebaker James W., Booth RJ., \& Francis ME. (2007). Linguistic inquiry and word count: LIWC [Computer software], Austin, TX: Liwc.Net.

Pennebaker James W., \& Francis ME. (1996). Cognitive, emotional, and language processes in disclosure. Cognition \& Emotion, 10(6), 601-626.

Pennebaker James W., Francis ME., \& Booth RJ. (2001). Linguistic inquiry and word count: LIWC 2001. Mahway: Lawrence Erlhaum Associates, 77(2001), 2001.

Pennebaker James W., Mayne TJ., \& Francis ME. (1997). Linguistic predictors of adaptive bereavement. Journal of Personality and Social Psychology, 72(4), 863. [PubMed: 9108699]

Pennebaker James W., Mehl MR., \& Niederhoffer KG. (2003). Psychological aspects of natural language use: Our words, our selves. Annual Review of Psychology, 57(1), 547-577.

Pennebaker James W., \& Seagal JD. (1999). Forming a story: The health benefits of narrative. Journal of Clinical Psychology, 55(10), 1243-1254. [PubMed: 11045774]

Petrie KJ, Booth RJ, Pennebaker JW, Davison KP, \& Thomas MG (1995). Disclosure of trauma and immune response to a hepatitis B vaccination program. Journal of Consulting and Clinical Psychology, 63(5), 787. [PubMed: 7593871]

Petrie KJ, Fontanilla T, Thomas MG, Booth RJ, \& Pennebaker JW (2004). Effect of written emotional expression on immune function in patients with human immunodeficiency virus infection: a randomized trial. Psychosomatic Medicine, 66(2),272-275. [PubMed: 15039514]

Ramirez-Esparza N, \& Pennebaker JW (2006). Do good stories produce good health?: Exploring words, language, and culture. Narrative Inquiry, 16( 1), 211-219.

Rude S, Gortner E-M, \& Pennebaker J (2004). Language use of depressed and depression-vulnerable college students. Cognition \& Emotion, 18(8), 1121-1133.

Schou I, Ekeberg, 0., \& Ruland, C. M. (2005). The mediating role of appraisal and coping in the relationship between optimism-pessimism and quality of life. Psycho-Oncology, 14(9), 718-727. [PubMed: 15669084]

Schwartz GE, Weinberger DA, \& Singer JA (1981). Cardiovascular Differentiation of Happiness, Sadness, Anger, and Fear Following Imagery and Exercisel. Psychosomatic Medicine, 43(4), $343-$ 364. [PubMed: 7280162]

Silverberg MJ, Leyden W, Horberg MA, DeLorenze GN, Klein D, \& Quesenberry CP (2007). Older age and the response to and tolerability of antiretroviral therapy. Archives of Internal Medicine, 167(7), 684-691. [PubMed: 17420427]

Sloan D, \& Marx B (2004). Taking Pen to Hand: Evaluating Theories Underlying the Written Disclosure Paradigm. Clinical Psychology Science and Practice, 11(2), 121-137.

Smith TW, Glazer K, Ruiz JM, \& Gallo LC (2004). Hostility, anger, aggressiveness, and coronary heart disease: An interpersonal perspective on personality, emotion, and health. Journal of Personality, 72(6), 1217-1270. [PubMed: 15509282]

Stanton AL, Danoff-Burg S, Sworowski LA, Collins CA, Branstetter AD, Rodriguez-Hanley A, ... Austenfeld L. (2002). Journal of Clinical Oncology 20(20), 4160-4168. [PubMed: 12377959]

Steptoe A, Dockray S, \& Wardle J (2009). Positive affect and psychobiological processes relevant to health. Journal of Personality, 77(6), 1747-1776. [PubMed: 19796062]

Tausczik YR, \& Pennebaker JW (2010). The psychological meaning of words: LIWC and computerized text analysis methods. Journal of Language and Social Psychology, 29(1), 24-54.

J Behav Med. Author manuscript; available in PMC 2019 December 01. 
Terzian AS, Holman S, Nathwani N, Robison E, Weber K, Young M, ... Gange SJ. (2009). Factors associated with preclinical disability and frailty among HIV-infected and HIV-uninfected women in the era of cART Journal of Women's Health, 18(12), 1965-1974.

Tugade MM, \& Fredrickson BL (2004). Resilient individuals use positive emotions to bounce back from negative emotional experiences. Journal of Personality and Social Psychology, 86(2), 320. [PubMed: 14769087]

Walsh JC, Mandalia S, \& Gazzard BG (2002). Responses to a 1 month self-report on adherence to antiretroviral therapy are consistent with electronic data and virological treatment outcome. Aids, 16(2), 269-277. [PubMed: 11807312]

Weinstein N, Brown KW, Ryan RM (2009). A multi-method examination of the effects of mindfulness on stress attribution, coping., and emotional well-being. Journal of Research in Personality 43(3), $374-385$.

Wilson TE, Weedon J, Cohen MH, Golub ET, Milam J, Young MA, ... Fredrickson BL. (2016).

Positive affect and its association with viral control among women with HIV infection. Journal of Health Psychology 36(1), 91-100.

Wright DO, Crawford E, Sebastian K (2007). Positive resolution of childhood sexual abuse experiences: The role of coping, benefit-finding and meaning-making. Journal of Family Violence 22(1), 597-608. 10.1007/s1Q896-007-9111-1

Ziemssen T, Kern S (2007). Psychoneuroimmunology-Cross-talk between the immune and nervous system. Journal of Neurology 25-/(Supp 2), 8-11. 10.1007/s00415-007-200308 


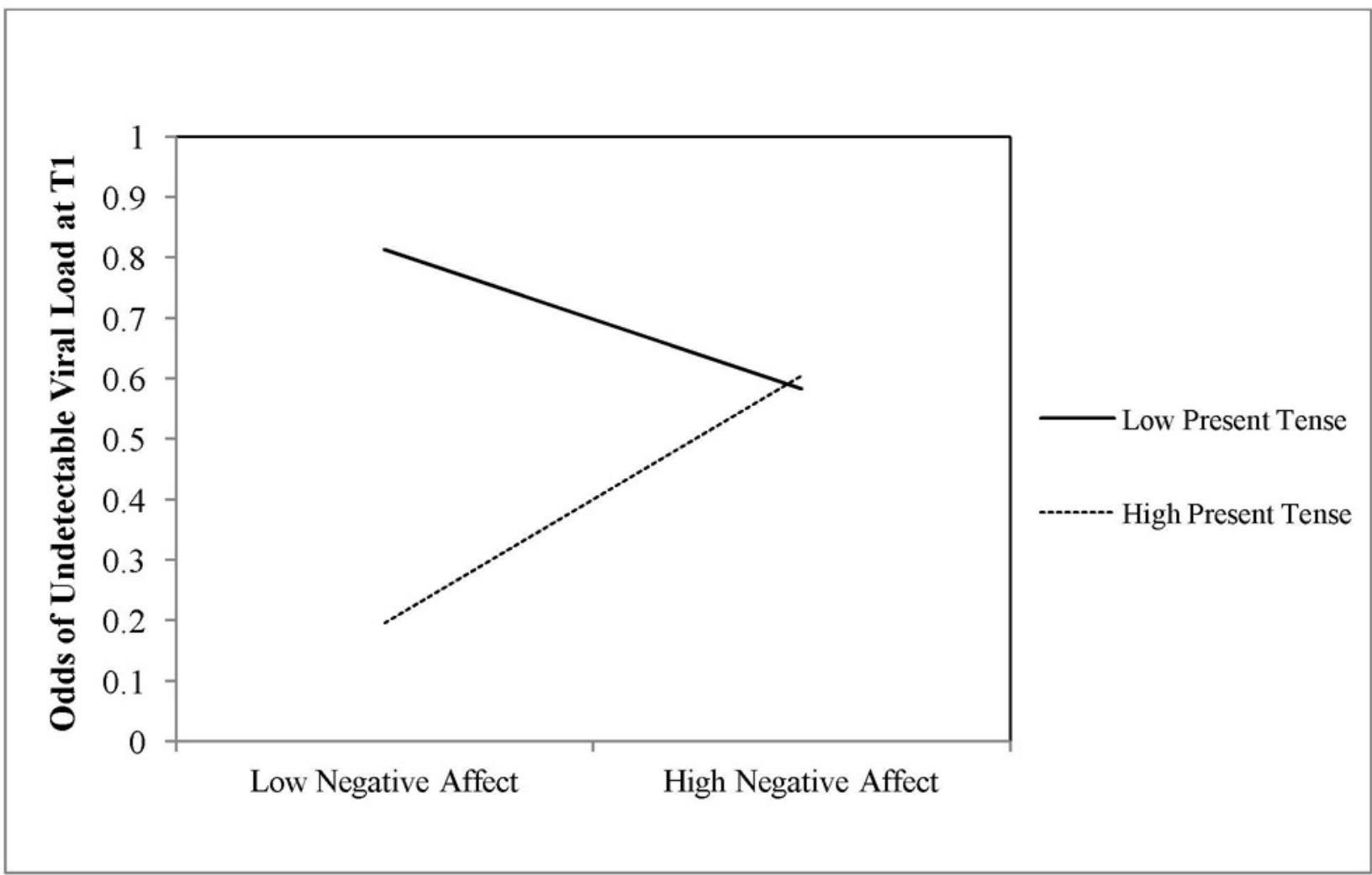

Figure 1. Odds Undetectable Viral Load at T1.

Here shown are the odds of having an undetectable viral load (<80 copies/ml of HIV RNA load) when participants used relatively low present tense words vs. high present tense words at low vs. high use of negative affect words. 


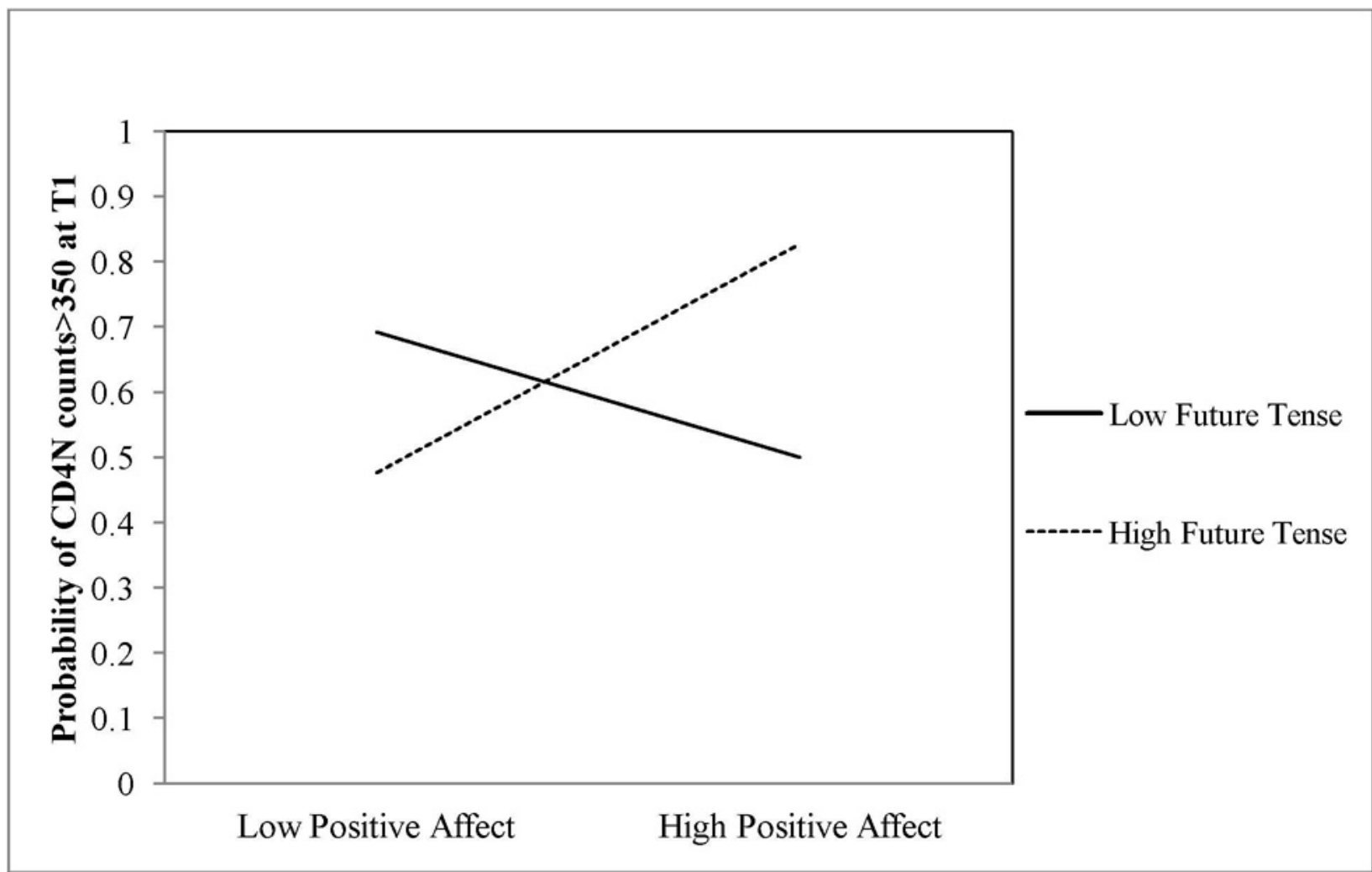

Figure 2. Odds CD4N Counts $>350$ at $\mathbf{T} 1$.

Here shown are the odds of having CD4+ cells $/ \mathrm{mm}^{3}$ counts greater than 350 when participants used relatively low future tense words vs. high future tense words at low vs. high use of positive affect words. 


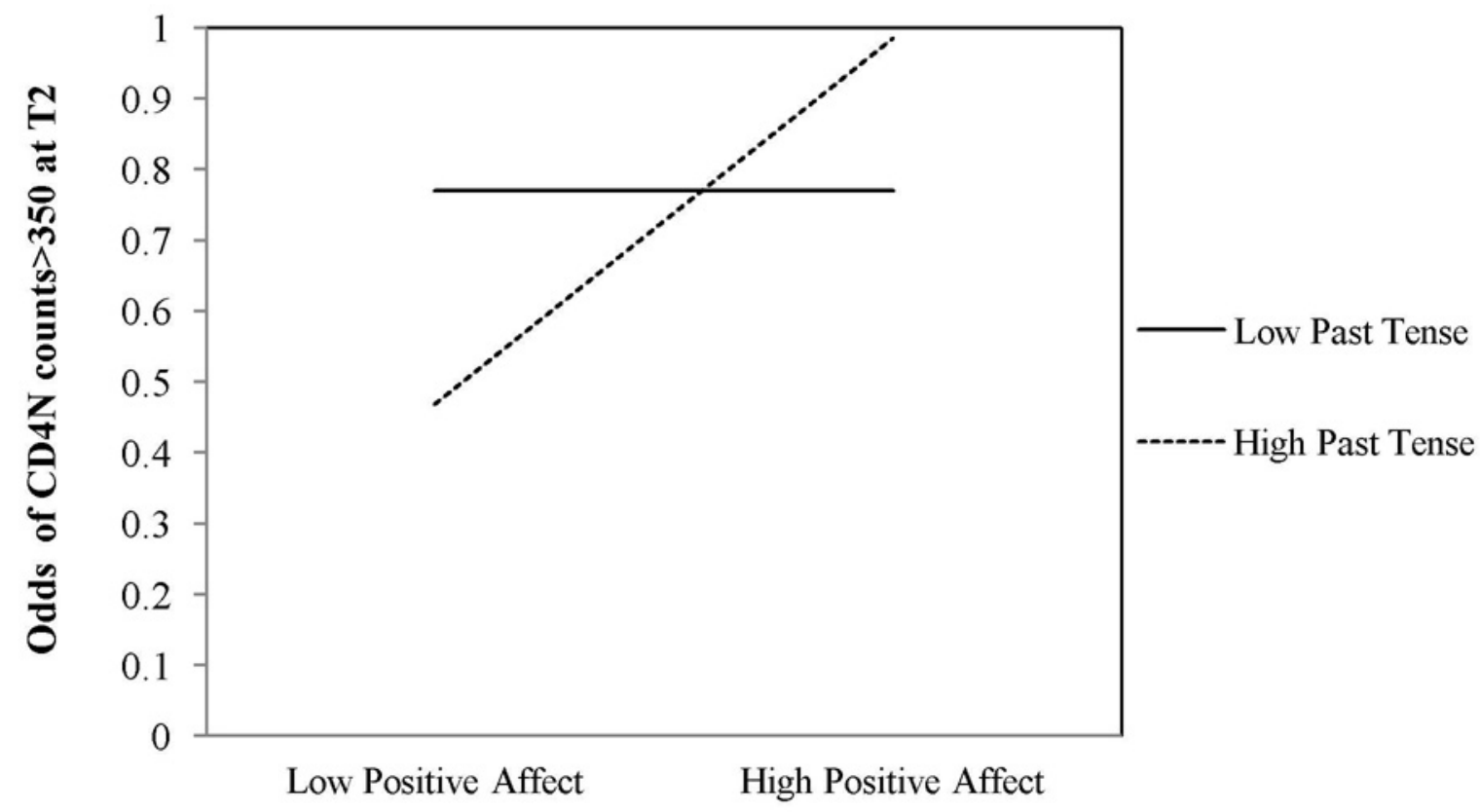

Figure 3. Odds CD4N Counts $>350$ at $\mathbf{T} 2$.

Here shown are the odds of having CD4+ cells $/ \mathrm{mm}^{3}$ counts greater than 350 at $\mathrm{T} 2$ when participants used relatively low past tense words vs. high past tense words at low vs. high use of positive affect words. 
Table 1:

Demographic Characteristics of Participants

\begin{tabular}{|c|c|c|}
\hline Characteristic & Frequency & Percentage \\
\hline $\operatorname{Age}(M, S D)$ & $45.32(8.87)$ & \\
\hline \multicolumn{3}{|l|}{ Reported Ethnicity } \\
\hline African American & 89 & $90.8 \%$ \\
\hline Non-Hispanic White & 4 & $4.1 \%$ \\
\hline Hispanic & 4 & $4.1 \%$ \\
\hline Other & 1 & $1 \%$ \\
\hline \multicolumn{3}{|l|}{ Education Level } \\
\hline Grades $1-6$ & 1 & $1 \%$ \\
\hline Grades $7-11$ & 43 & $43.9 \%$ \\
\hline High School Graduate & 30 & $30.6 \%$ \\
\hline Some College & 19 & $19.4 \%$ \\
\hline College Graduate & 4 & $4.1 \%$ \\
\hline Attended/Completed Graduate School & 1 & $1 \%$ \\
\hline \multicolumn{3}{|l|}{ Household Income } \\
\hline$<\$ 6,001$ & 26 & $26.5 \%$ \\
\hline$\$ 6001-12000$ & 41 & $41.8 \%$ \\
\hline$\$ 12001-18000$ & 15 & $15.3 \%$ \\
\hline$\$ 18001-24000$ & 6 & $6.1 \%$ \\
\hline$\$ 24001-30000$ & 2 & $2 \%$ \\
\hline$\$ 30001-36000$ & 2 & $2 \%$ \\
\hline$\$ 36001-75000$ & 4 & $4.1 \%$ \\
\hline$>\$ 75,000$ & 2 & $2 \%$ \\
\hline
\end{tabular}


Table 2:

Descriptive statistics for predictor variables

\begin{tabular}{|c|c|c|c|c|c|}
\hline Predictor & $\mathbf{N}$ & Min. & Max & $\mathbf{M}$ & SD \\
\hline Elapsed time in days & 98 & 84 & 270 & 171.63 & 45.11 \\
\hline Positive Affect & 98 & .82 & 5.12 & 2.12 & .86 \\
\hline Negative Affect & 98 & .00 & 2.96 & 1.29 & .61 \\
\hline Past Tense & 98 & 2.36 & 11.56 & 8.11 & 1.80 \\
\hline Present Tense & 98 & 3.04 & 15.65 & 6.82 & 2.08 \\
\hline Future Tense & 98 & .00 & 1.25 & .51 & .28 \\
\hline
\end{tabular}

Note: Means for the linguistic features are presented as percentages of total words used in the narratives. 
Table 3:

Hierarchical Logistic Regressions of Word Tense \& Affect Predicting HIV related Health Indicators at $\mathbf{T 1}$

\begin{tabular}{|c|c|c|c|c|c|c|c|c|c|}
\hline \multirow[b]{2}{*}{ Variable } & \multicolumn{3}{|c|}{ T1 Adherence ( $N=94)$} & \multicolumn{3}{|c|}{$\begin{array}{l}\text { T1 Undetectable Viral Foad } \\
(N=98)\end{array}$} & \multicolumn{3}{|c|}{ T1 CD4N>350 $(N=98)$} \\
\hline & \multicolumn{2}{|c|}{ OR $(95 \%$ CI $)$} & $\begin{array}{c}\mathbf{p} \\
\text { value }\end{array}$ & \multicolumn{2}{|c|}{ OR $(95 \% \mathrm{CI})$} & $p$ value & \multicolumn{2}{|c|}{ OR $(95 \% \mathrm{CI})$} & $\begin{array}{c}\mathbf{p} \\
\text { value }\end{array}$ \\
\hline $\begin{array}{l}\text { Recruitment } \\
\text { Wave }\end{array}$ & .71 & $\begin{array}{l}(-41- \\
1.22)\end{array}$ & .213 & .84 & $\begin{array}{l}(.53- \\
1.34)\end{array}$ & .463 & .84 & $\begin{array}{l}(.53- \\
1.34)\end{array}$ & .469 \\
\hline Age & 1.41 & $\begin{array}{l}(.79- \\
2.52)\end{array}$ & .243 & 1.53 & $\begin{array}{l}(.90- \\
2.60)\end{array}$ & .115 & 1.00 & $\begin{array}{l}(.60- \\
1.66)\end{array}$ & .997 \\
\hline \multicolumn{10}{|l|}{ Step 2} \\
\hline Positive Affect & 1.48 & $\begin{array}{l}(.78- \\
2.78)\end{array}$ & .228 & 1.05 & $\begin{array}{l}(.63- \\
1.76)\end{array}$ & .849 & 1.12 & $\begin{array}{l}(.66- \\
1.89)\end{array}$ & .668 \\
\hline Negative Affect & 1.00 & $\frac{(.60-}{1.65)}$ & .999 & 1.35 & $\frac{(.83-}{2.20)}$ & .224 & 1.38 & $\frac{(.85-}{2.22)}$ & .191 \\
\hline Past Tense & .66 & $\frac{(.38-}{1.15)}$ & .141 & .53 & $\begin{array}{l}(.32- \\
.89)\end{array}$ & .016 & .54 & $(.32-.92)$ & .022 \\
\hline Present Tense & .87 & $\frac{(.49-}{1.55)}$ & .631 & .52 & $\begin{array}{l}(.30- \\
.92)\end{array}$ & .024 & .80 & $\begin{array}{l}(.47- \\
1.36)\end{array}$ & .409 \\
\hline Future Tense & 1.04 & $\frac{(.63-}{1.71)}$ & .889 & 1.40 & $\frac{(.87-}{2.27)}$ & .167 & 1.09 & $\frac{(.68-}{1.74)}$ & .725 \\
\hline
\end{tabular}


Table 4:

Hierarchical Logistic Regressions of Word Tense \& Affect Predicting HIV related Health Indicators at $\mathbf{T} 2$

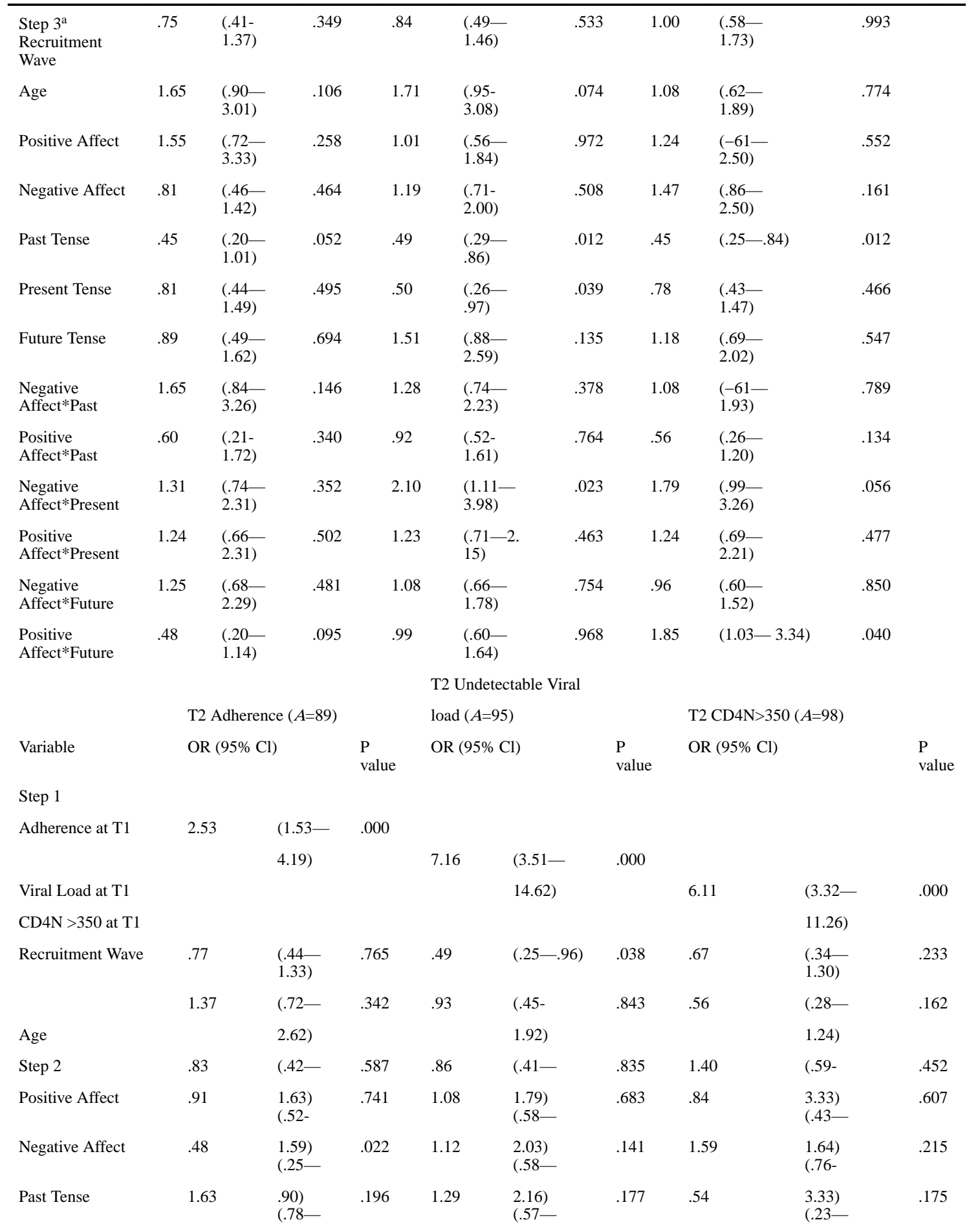

J Behav Med. Author manuscript; available in PMC 2019 December 01. 


\begin{tabular}{|c|c|c|c|c|c|c|c|c|c|c|}
\hline & Present Tense & 1.43 & $\begin{array}{l}3.41) \\
(.81-\end{array}$ & .218 & .91 & $\begin{array}{l}2.88) \\
(.47-\end{array}$ & .797 & 2.35 & $\begin{array}{l}1.31) \\
(1.09-\end{array}$ & .029 \\
\hline \multirow{7}{*}{ 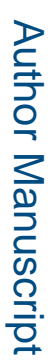 } & Future Tense & & $2.51)$ & & & 1.73) & & & $5.05)$ & \\
\hline & Step $3^{\mathrm{a}}$ & 3.71 & $(1.80-$ & .000 & & & & & & \\
\hline & Adherence at $\mathrm{T} 1$ & & 7.63) & & 9.50 & $(3.90-$ & .000 & & & \\
\hline & Viral Load at $\mathrm{T} 1$ & & & & & 23.15) & & 15.18 & $(4.73-$ & .000 \\
\hline & $\mathrm{CD} 4 \mathrm{~N}>350$ at $\mathrm{T} 1$ & & & & & & & & 48.64) & \\
\hline & & .55 & $(.26-$ & .116 & .52 & $(.25-$ & .088 & .70 & $(.30-$ & .405 \\
\hline & Recruitment Wave & & $1.16)$ & & & 1.10) & & & 1.64) & \\
\hline & & 1.40 & $(.62-$ & .416 & .99 & $(.44-$ & .970 & .39 & $(.13-$ & .089 \\
\hline \multirow{14}{*}{ 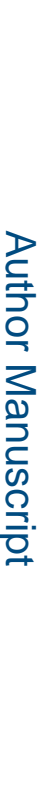 } & Age & & $3.17)$ & & & 2.19) & & & $1.15)$ & \\
\hline & & .89 & $(.39-$ & .788 & .64 & $(.25-$ & .348 & 2.96 & $(.88-$ & .080 \\
\hline & Positive Affect & & 2.03) & & & 1.64) & & & 9.94) & \\
\hline & & .71 & $(.35-$ & .329 & 1.41 & $(.63-$ & .407 & .73 & $(.29-$ & .498 \\
\hline & Negative Affect & & 1.42) & & & $3.17)$ & & & $1.82)$ & \\
\hline & & .44 & $(.19-$ & .052 & .94 & $(.44-$ & .870 & 1.52 & $(.71-$ & .280 \\
\hline & Past Tense & & 1.01) & & & 2.01) & & & 3.23) & \\
\hline & & 1.84 & $(.68-$ & .230 & .86 & $(.35-$ & .738 & .44 & $(.14-$ & .157 \\
\hline & Present Tense & & 4.99) & & & 2.12) & & & 1.37) & \\
\hline & & 1.99 & $(.90-$ & .089 & 1.00 & $(.47-$ & .993 & 4.11 & $(1.16-$ & .028 \\
\hline & Future Tense & & 4.34) & & & 2.16) & & & 14.51) & \\
\hline & $\begin{array}{l}\text { Negative } \\
\text { Affect*Past }\end{array}$ & 1.92 & $\begin{array}{l}(.91- \\
4.03)\end{array}$ & .086 & .80 & $\begin{array}{l}(.42- \\
1.54)\end{array}$ & .506 & 1.14 & $\begin{array}{l}(.53- \\
2.45)\end{array}$ & .744 \\
\hline & $\begin{array}{l}\text { Positive } \\
\text { Affect*Past }\end{array}$ & 1.51 & $\frac{(.64-}{3.56)}$ & .349 & 1.01 & $\begin{array}{l}(.56- \\
1.82)\end{array}$ & .966 & 2.96 & $(1.33-6.58)$ & .008 \\
\hline & $\begin{array}{l}\text { Negative } \\
\text { Affect*Present }\end{array}$ & .50 & $\begin{array}{l}(.22- \\
1.15)\end{array}$ & .103 & .90 & $\begin{array}{l}(.37- \\
2.23)\end{array}$ & .825 & .69 & $\begin{array}{l}(.26- \\
1.85)\end{array}$ & .465 \\
\hline \multirow{2}{*}{ 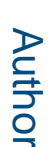 } & $\begin{array}{l}\text { Positive } \\
\text { Affect*Present }\end{array}$ & 1.50 & $\begin{array}{l}(.51- \\
4.47)\end{array}$ & .463 & 2.04 & $\begin{array}{l}(.87- \\
4.76)\end{array}$ & TOO & 1.62 & $\begin{array}{l}(.40- \\
6.61)\end{array}$ & .501 \\
\hline & $\begin{array}{l}\text { Negative } \\
\text { Affect*Future }\end{array}$ & .60 & $\begin{array}{l}(.33- \\
1.07)\end{array}$ & .083 & .94 & $\begin{array}{l}(.53- \\
1.67)\end{array}$ & .831 & 1.04 & $\begin{array}{l}(.54- \\
2.02)\end{array}$ & .904 \\
\hline$\frac{1}{010}$ & $\begin{array}{l}\text { Positive } \\
\text { Affect*Future }\end{array}$ & 1.41 & $\begin{array}{l}(.70- \\
2.84)\end{array}$ & .335 & .75 & $\begin{array}{l}(.37- \\
1.54)\end{array}$ & .430 & 2.82 & (TOIL40) & .146 \\
\hline
\end{tabular}

